Article

\title{
Application of corporate social responsibility -- Taking Chi- nese Listed Companies in the COVID-19 as an example
}

\author{
Chih-Yi Hsiao $^{1 *}$, Hao-Wei Chen ${ }^{2}$ \\ 1 Xiamen University Tan Kah Kee College, Zhangzhou, China 1; cyhsiaol@xujc.com \\ 2 Xiamen University Tan Kah Kee College, Zhangzhou, China 2; tax18050@stu.xujc.com \\ * Correspondence: cyhsiaol@xujc.com; Tel.: +86-596-6288885
}

\begin{abstract}
This study focuses on a sample of Chinese listed companies from 2019 to 2020 to explore the relationships among corporate social responsibility, financial constraints, and financial performance. In addition, we discuss five factors affecting financial constraints. We also analyze the types of enterprises that can improve their financial performance by implementing corporate social responsibility keeping in mind the factors that lead to a high degree of financial constraint. The results indicate that: 1 . The degree of financial constraints has a negative and significant impact on financial performance; 2 . There is a reverse relationship between the degree of financial constraints and the effectiveness of corporate social responsibility measures; 3. Enterprises with high financial constraints (due to lower financial slack and revenue growth rates) can significantly improve their financial performance through the implementation of effective corporate social responsibility programs. 4. Enterprises with high financial constraints, caused by financial slack and revenue growth rate, can significantly improve their financial performance by implementing corporate social responsibility programs.
\end{abstract}

Keywords: Financial constraints; corporate social responsibility; financial performance

\section{Introduction}

Capital and enterprise operations are closely related; therefore, capital costs and business management have been topics under close review in recent decades. The theory of financial constraints provides inspiration for relevant research on enterprise capital. Kaplan \& Zingales (1997) summarized the definition of financial constraints as follows: due to the influence of market information asymmetry and agency cost, the financial costs inside and outside enterprises are different. Higher financial constraints hinder enterprises from coping with day-to-day operations and investment projects of the business. There are many real-world cases where corporate social responsibility (CSR) programs/actions have supported companies' financial recovery.

ERKE, a Chinese sporting goods brand, donated 10 million yuan for COVID-19 relief in 2020, and donated 50 million yuan in July 2021 to aid with the aftermath of the heavy rain disaster in Henan province. Since its establishment in 2000, the company has developed rapidly. The group owns more than 7000 stores worldwide and has been outstanding in many brand evaluations in previous years. It was listed on the Singapore stock exchange in 2005. However, due to serious losses, it was suspended in 2011 and delisted in 2020. ERKE lost as much as 220 million yuan in 2020, with an additional loss of more than 60 million yuan in the first quarter of 2021. After the disaster relief efforts of the company spread, support from domestic consumers increased sharply, and the company then faced a situation of over-booking and excessive demand over production capability. This is a positive example where the implementation of CSR efforts reversed the disadvantages of 
enterprise management. Inspired by this case, this study explores the relationships among financial constraints, CSR, and financial performance.

Most existing literature discuss the impact of financial constraints or CSR on financial performance and most of them conduct empirical research based on the overall indicators of financial constraints. This study comprehensively explores the relationship among these three elements and explores the constituent elements of financial constraints in detail to analyze the characteristics of enterprises that are more capable of improving financial performance via CSR implementation. We expect the results of this study to provide a reference basis for enterprises to develop complete strategies within their respective financial constraints.

\section{Literature review}

2.1 Corporate social responsibility and environment, social and governance (ESG) policies

\subsubsection{The definition and connotation of CSR and ESG}

So far, there is no universal definition for CSR, and this has contributed to the ineffective global regulation of the field. However, the definition of CSR given by world-renowned institutions and scholars can be summarized as follows: the behavior of all stakeholders associated with business activities should conform to ethics. It includes the aspects of environment, economy, labor rights, social care, and legal compliance. With the rise of the concept of CSR, people's judgment of investment targets is gradually incorporated into the performance of corporate social responsibility. Therefore, the ESG investment method has become a trend. ESG originated from Socially Responsible Investment(SRI) in Europe and America in recent decades. Investors now believe that the evaluation of investment targets should focus not only on financial performance, but also on non-financial aspects, that is, CSR performance. In the abbreviation ESG, "E" (Environment) represents the company's feedback on environmental problems in the process of operation, such as energy conservation and emission reduction, sewage treatment, and other related environmental protection behaviors; "S" (Society) represents the social responsibility of the company, such as charitable acts, disaster donations, and poverty donations and acts such as protecting the rights of the company's employees and their responsibilities to customers or manufacturers;

"G" (Governance) represents the internal governance structure and management system of the company. The world's first ESG fund was established in the United States in 1971, and the world's first ESG index fund was established in 1990. Later, the United Nations established the United Nations' supported principles for responsible investment (UNPRI) in 2006, of which more than 80\% were signatories from European and American countries, indicating that ESG investment in Europe and America had been widely recognized at that time. After the concept of ESG was put forward, it became an evaluation standard for corporate responsibility investment, also playing an important supplementary role in traditional credit rating (Liu and $\mathrm{Yu}, 2021$ ), which is usually a positive role in the overall credit rating ( $\mathrm{Kim}$ and $\mathrm{Li}, 2021$ ).

\subsubsection{Current development of ESG in China and the world}

Globally, ESG has been promoted by many global organizations, such as the GRI guidelines for sustainable development reports issued by the Global Reporting Initiative (GRI) and non-profit sustainable accounting standards issued by the non-profit sustainable Accounting Standards Committee. In recent years, ESG rating systems and indices have been established successively, such as the Fitch Ratings ESG credit rating system, MSCI ESG index, and S\&P 500 ESG index.

China's ESG began relatively late. The Shenzhen Stock Exchange issued guidelines on CSR for listed companies on the Shenzhen Stock Exchange in 2006. Later, in 2008, the Shanghai Stock Exchange issued instructions on strengthening CSR for listed companies. In 2015, the General Administration of Quality Supervision, Inspection, and Quarantine 
of the People's Republic of China and Standardization Administration of the People's Republic of China issued the Guidance on Social Responsibility. The China Securities Regulatory Commission revised the guidelines for the governance of listed companies in 2018, adding new content such as stakeholders, environmental protection, and social responsibility requiring listed companies to practice the concept of green development and to actively assume social responsibility. The Industrial and Commercial Bank of China (ICBC) has also attempted to build and test the ESG green rating system (Zhang et al., 2017). In terms of the specification of corporate social responsibility report disclosure, the Global Reporting Initiative (GRI) published the first edition of the Sustainable Development Reporting Guidelines in 2000 and the latest GRI standards in 2016. Currently, GRI reporting guidelines are the most widely recognized social responsibility reporting framework in the world. The initiative of enterprises to disclose high-quality social responsibility reports helps enterprises treat their social responsibility behaviors more rigorously and reduce errors, thereby helping improve financial performance (Zhong et al., 2021).

ESG was developed earlier and thus became more mature in western countries. However, although China started slowly, it has developed rapidly. Various research documents and government policies have been issued. The importance of ESG is expected to grow in the future.

2.2 Definition, indices, and evaluation models of financial constraints

\subsubsection{Definition of financial constraints}

To date, there is no globally consistent definition of financial constraints. Referring to the definitions given by well-known scholars at home and abroad, including Modigliani \& Miller (1958), in the operation of the perfect capital market, the internal and external capital of the enterprise can completely replace each other, so the investment behavior of the enterprise will not be affected by the financial situation of the enterprise itself. In reality, however, the capital market is imperfect. Information asymmetry leads to enterprises' inability to grasp external financial information, and banks charge handling fees as agency costs, which lead to an increase in external financial costs. This difference in internal and external financial costs, that is, the degree of financial constraints faced by enterprises, is positively related to the degree of information imbalance (Greenwald et al., 1984; Myers and Majluf, 1984; Kaplan and Zingales, 1997). Fazzari et al. (1988) believe that, in addition to the gap between the internal and external financial costs caused by imperfections in the capital market, the dividend payment rate also affects the retained earnings of the enterprise, and consequently affects the funds retained within the enterprise. Therefore, the dividend payment rate of an enterprise is also one of the elements that measures the degree of financial constraints. Bernanke \& Gertler (1989) further found that, due to the influence of financial constraints, the investment behavior of enterprises depends not only on investment demand but also on their own internal capital. Based on the research theories of the above scholars, follow-up research on financial constraints mostly focuses on information asymmetry and agency costs. A number of studies have proven the existence of many factors affecting financial constraints, such as the negative correlation between R\&D investment and political relevance (Yan and Jiang, 2019). Another example is that competition among banks can ease corporate financial constraints (Jiang et al., 2019; Zhang et al., 2019).

\subsubsection{The evaluation models of financial constraints}

Financial constraint indicators mainly include the FHP model (Fazzari, Hubbard and Petersen, 1988), KZ index (Kaplan and Zingales, 1997), WW index (Whited and Wu, 2006), and SA index (Hadlock and Pierce, 2010). Some models or indices are built by domestic scholars. For example, Zhai et al. (2012) constructed a financial constraint evaluation model. 
The FHP calculation model is an investment function model established by Fazzari, Hubbard, and Petersen with fixed asset investment as the dependent variable and Tobin's $\mathrm{Q}$ and cash flow as independent variables.

$$
(\mathrm{I} / \mathrm{K})_{i, t}=\mathrm{f}(\mathrm{X} / \mathrm{K})_{i, t}+\mathrm{g}(\mathrm{CF} / \mathrm{K})_{i, t}+v_{i, t},
$$

where (I / K) represents the ratio of the company's investment in fixed assets to the total capital at the beginning of the period in phase $t, X$ represents the variable that theoretically determines the investment demand, CF refers to the internally generated cash flow coefficient, $g$ refers to the sensitivity of the investment to the fluctuation of internal financial, and Tobin's Q - the company's market price (share price) / the company's replacement cost.

Lamont and Polk (2001) constructed a calculation model of the KZ index by selecting the company's operations based on the research of Kaplan and Zingales. The larger the value of the KZ index, the higher the degree of financial constraints. The calculation model is as follows:

$$
\begin{gathered}
K Z_{i t}=-1.001909 * \text { OCF }_{i t} / \text { Asset }_{i t}+3.139193 * \text { Lev }_{i t}-39.3678 * \text { Dividends }_{i t} / \text { Asset }_{i t} \\
-1.314759 * \text { Cash }_{i t} / \text { Asset }_{i t}+0.2826389 * \text { Tobin's }_{i t}
\end{gathered}
$$

OCF refers to operating cash flow, asset refers to total assets, dividends refer to dividends paid out, cash refers to cash holding level and the above are standardized total assets at the beginning of the period. Lev refers to the asset liability ratio and Tobin's $Q$ refers to Tobin's $Q$ value [market price (share price) / replacement cost of the company].

The calculation model of the WW index is constructed by Whited and Wu from the linear combination of six indicators: virtual variable of dividend payment, cash flow, asset liability ratio, company size, and sales growth rate of the company and industry. The calculation model is as follows:

$W W_{i t}=-0.091 * C F_{i t}-0.062 *$ DIVPOS $_{i t}+0.021 *$ TLTD $_{i t}-0.044 * L_{N T A_{i t}}+$ $0.1021 * S G_{i t}-0.035 * S G_{i t} \mathrm{CF}$ refers to the ratio of cash flow to total assets, and DIVPOS is an indicator. If the company pays cash dividends, the value is "1"; TLTD is the ratio of long-term debt to total assets; LNTA is the natural logarithm of total assets; ISG is the company's three-digit industry sales growth; SG is a solid sales growth.

Hadlock and Pierce (2010) classified the financial constraints of companies randomly sampled from 1995 to 2004. Estimated Ordered Logit Model Prediction was used. The research results cast considerable doubt on whether the $\mathrm{KZ}$ index is effective as a measure of financial constraints. This shows that the measurement of financial constraints of the $\mathrm{KZ}$ index may be inaccurate owing to many endogenous factors. Based on this, a calculation model for the SA index is proposed. The calculation model is as follows:

$$
S A_{i t}=-0.737 * S I Z E_{i t}+0.043 * S I Z E_{i t}^{2}-0.04 * A G E_{i t}
$$

Here, size and age refer to the size and age of the company. These two elements are basic elements based only on the company's characteristics.

After comprehensively considering classical evaluation models such as FHP, KZ, and WW, based on the differences between China's financial system and foreign development, Chinese scholar Zhai et al. (2012) improved the original variables and developed a financial constraint evaluation model that is more suitable for Chinese enterprises with stochastic frontier equations. The model is as follows:

$$
\begin{gathered}
F C_{i, t}=-8.530658 * \Delta P R_{i, t}-0.4599886 * S_{Z} I Z E_{i, t}-0.0030249 * S L A C K_{i, t} \\
-2.453183 * C F_{i . t} / A_{i, t-1}-1.304857 * S G R_{i, t}
\end{gathered}
$$

Among them, FC represents the degree of enterprise financial constraints, and the greater the absolute value of $\mathrm{FC}$, the smaller the degree of financial constraints. $\triangle \mathrm{PR}$ represents the change in dividend per share, that is, cash dividends per share in the current year, and cash dividends per share in the last year. Size represents the size of the company, expressed as the natural logarithm of the company's total assets at the end of the period. Slack is financial slack, and the calculation formula is [(cash + trading financial assets +0.5 * inventory $+0.7 *$ accounts receivable - short-term loans) / net value of fixed assets]. CF / a represents the proportion of cash flow in total assets at the end of the previous period. 
SGR is the growth rate of operating revenue as equal to [(operating revenue of the current year - operating revenue of last year) / operating revenue of last year].

2.3 Literature on the relationship between financial constraints and CSR

The research results from Chen and Chen (2020) show that the degree of financial constraints affects the willingness of enterprises to implement social responsibility. Enterprises tend to reduce expenses to prevent and control business risks, and CSR is an expense item that is easier for management to reduce. Li et al. (2020) empirically discussed the relationship between political relevance, chain director networks (belonging to the governance scope of ESG), and CSR. The research findings show that enterprises with high political relevance will strengthen the positive impact of chain director networks on the implementation of social responsibility, and the strengthening function of central political relevance is more obvious than that of local political relevance. The above studies show that the higher the degree of financial constraints, the worse the implementation performance of social responsibility. The research hypothesis of this study is summarized as follows:

H1: There is a negative correlation between the degree of corporate financial constraints and performance of social responsibility implementation.

2.4 Literature on the relationship between financial constraints and financial performance

Using private companies as samples, Zhang et al. (2021) used an OLS regression model to study the relationship between financial constraints and financial performance. They found that there was a negative correlation between financial constraints and financial performance when other conditions remained unchanged. Li et al. (2021) took 1,645 A-share listed companies as samples and found that there was a negative correlation between financial constraints and corporate performance, and the uncertainty of economic policy regulates the negative correlation effect of financial constraints on corporate performance. The level of internal control determines the adjustment ability of economic policy uncertainty. The higher the level, the stronger the adjustment ability. Based on the data of Shanghai and Shenzhen A-share listed companies from 2012 to 2018, Zhang (2019) found a negative relationship between financial constraints and corporate performance. At the same time, it is affected by the investment efficiency. The higher the investment efficiency, the stronger the negative impact. Scholars have found that the overall financial constraint indicators have no significant impact on corporate performance (Gu et al., 2018). Based on the above literature, we draw the following conclusions. 1. More literature shows that there is a negative correlation between financial constraints and corporate performance. 2. Under some conditions, financial constraints affect the ability of some indicators to promote corporate performance, but these conclusions may not be universal. Therefore, this study proposes the following hypothesis:

$\mathrm{H} 2$ : There is a negative correlation between the degree of corporate financial constraints and financial performance.

2.5 Literature on the relationship between ESG and financial performance

Broadstock et al. (2019) found that the formulation of sound CSR and ESG strategies has a positive impact on corporate value and business performance, and this is a process of "indirect value creation." Brogi \& Lagasio (2018) evaluated a method of indexing ESG scores of U.S. listed companies based on MSCI ESG ratings (formerly KLD) statistical data from 2000 to 2016, and studied the relationship between return on assets and three dimensions of ESG. The study found that there was a significantly positive relationship between ESG and a bank's environmental awareness and profitability. De Lucia et al. (2020) used a combination of machine learning technology and reasoning technology to predict the accuracy of ESG and financial performance (return on assets/ROA and return on equity/ROE), and whether there is a relationship between ESG investment decisions and 
ROA and ROE. The research findings show that machine learning technology can accurately predict financial performance, and that there is a significant positive relationship between ESG practices and financial performance through a regression model.

However, some scholars have held different views. Uyar et al. (2020) showed that a CSR committee with at least one female member, will be a favorable factor in promoting the excellent performance of enterprises in ESG. In the field of corporate governance, the due diligence investment of independent directors and directors can significantly improve the overall CSR score; However, there is no significant correlation between CSR performance and financial performance. Nevertheless, most studies tend to show a positive correlation between the two variables. Therefore, the third research hypothesis of this study is as follows:

H3: The better the implementation of CSR, the better the financial performance of the enterprise.

2.6 Literature on the relationship between ESG, financial constraints and financial performance

Leong \& Yang (2021) believe that enterprises with higher financial constraints strengthen their social attention to their social responsibility, resulting in a significant weakening of their overall CSR performance. Zhu et al. (2016) believe that the better the CSR performance, the better the corporate performance and the higher the degree of financial constraints, the worse the CSR performance. The higher degree of financial constraints will significantly reduce the promotion of CSR performance on corporate financial performance.

There is a dearth of literature on the relationship between these three factors. The main conclusion of the literature that can be consulted at present is that the correlation between the degree of financial constraints and financial performance is negative, and social responsibility plays the role of an intermediary variable between financial constraints and financial performance. Therefore, the fourth hypothesis of this study is as follows.

H4: CSR mediates the relationship between financial constraints and corporate financial performance.

\section{Methodology}

According to the hypotheses summarized in the literature review, this study explores the relationships among financial constraints, CSR performance, and financial performance. The relationship between these three elements is shown in Figure 1.

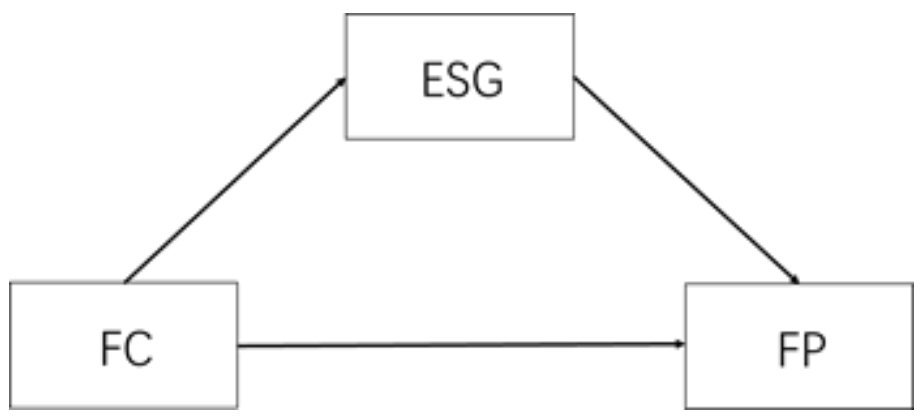

Figure 1. The relationship between financial constraints, corporate social responsibility, and financial performance

The study sample is China's A-share listed companies rated by the ESG. At present, there are many ESG rating agencies for listed companies in China, such as the Sino-Securities Index, FTSE Russell, China Alliance of Social Value Investment, and Rankins CSR Rating (RKS). This study adopts the rating results of the Sino-Securities Index, which was established in September 2017. It is an independent third-party professional service agency for various asset management institutions, mainly providing comprehensive services for index and indexed investments. Moreover, the company obtained authorization from both the Shanghai and Shenzhen Stock Exchanges, focusing 
on the R\&D of index and index investment. It also provides whole industry chain services, including research and consulting, product design, marketing promotion, valuation, and data information. Its rating method has the characteristics of being close to the Chinese market, wide coverage, and efficient timeliness, and includes all A-share listed companies. Thus, this study employs the rating results of the Sino-Securities Index as the most suitable research sample. The research periods were 2019 and 2020. All the sample data were taken from the WIND and CSMAR databases. After data download, incomplete samples are deleted first, extreme values are deleted next, and a total of 7,315 samples are obtained.

First, we investigate the relationships among financial constraints, CSR, and corporate financial performance. Second, this study explores whether CSR plays a mediating role between financial constraints and corporate financial performance, referring to the mediator test approach of Wen and Ye (2014), and establishes the following models to inspect the intermediary role of CSR between financial constraints and financial performance.

Model 1:

$$
\begin{aligned}
R O A_{i t}= & \alpha_{0}+\alpha_{1} F C_{i t}+\alpha_{2} S C A L E_{i t}+\alpha_{3} F C F_{i t}+\alpha_{4} S G R_{i t}+\alpha_{5} D E B T_{i t}+\alpha_{6} A G E_{i t}+ \\
& \alpha_{7} S T A T E_{i t}+\alpha_{8} Y E A R_{i t}+\varepsilon_{i t} \ldots \ldots \ldots \ldots \ldots \ldots \ldots .1 \\
E S G_{i t}= & \beta_{0}+\beta_{1} F C_{i t}+\beta_{2} S C A L E_{i t}+\beta_{3} F C F_{i t}+\beta_{4} S G R_{i t}+\beta_{5} D E B T_{i t}+\beta_{6} A G E_{i t}+ \\
& \beta_{7} S T A T E_{i t}+\beta_{8} Y E A R_{i t}+\varepsilon_{i t} \ldots \ldots \ldots \ldots \ldots \ldots \ldots \ldots .1-2 \\
R O A_{i t}= & \gamma_{0}+\gamma_{1} F C_{i t}+\gamma_{2} E S G_{i t}+\gamma_{3} S C A L E_{i t}+\gamma_{4} F C F_{i t}+\gamma_{5} S G R_{i t}+\gamma_{6} D E B T_{i t}+\gamma_{7} A G E_{i t}+ \\
& \gamma_{8} S T A T E_{i t}+\gamma_{9} Y E A R_{i t}+\varepsilon_{i t} \ldots \ldots \ldots \ldots 1-3
\end{aligned}
$$

Model 2

$$
\begin{aligned}
R O E_{i t}= & \alpha_{0}+\alpha_{1} F C_{i t}+\alpha_{2} S C A L E_{i t}+\alpha_{3} F C F_{i t}+\alpha_{4} S G R_{i t}+\alpha_{5} D E B T_{i t}+\alpha_{6} A G E_{i t}+ \\
& \alpha_{7} S T A T E_{i t}+\alpha_{8} Y E A R_{i t}+\varepsilon_{i t} \ldots \ldots \ldots \ldots \ldots \ldots \ldots \ldots . .2-1 \\
E S G_{i t}= & \beta_{0}+\beta_{1} F C_{i t}+\beta_{2} S C A L E_{i t}+\beta_{3} F C F_{i t}+\beta_{4} S G R_{i t}+\beta_{5} D E B T_{i t}+\beta_{6} A G E_{i t}+ \\
& \beta_{7} S T A T E_{i t}+\beta_{8} Y E A R_{i t}+\varepsilon_{i t} \ldots \ldots \ldots \ldots \ldots \ldots \ldots \ldots \ldots .2-2 \\
R O E_{i t}= & \gamma_{0}+\gamma_{1} F C_{i t}+\gamma_{2} E S G_{i t}+\gamma_{3} S C A L E_{i t}+\gamma_{4} F C F_{i t}+\gamma_{5} S G R_{i t}+\gamma_{6} D E B T_{i t}+\gamma_{7} A G E_{i t}+ \\
& \gamma_{8} S T A T E_{i t}+\gamma_{9} Y E A R_{i t}+\varepsilon_{i t} \ldots \ldots \ldots \ldots \ldots .2-3
\end{aligned}
$$

The flow chart of the mediating effect of the above model is as follows: 


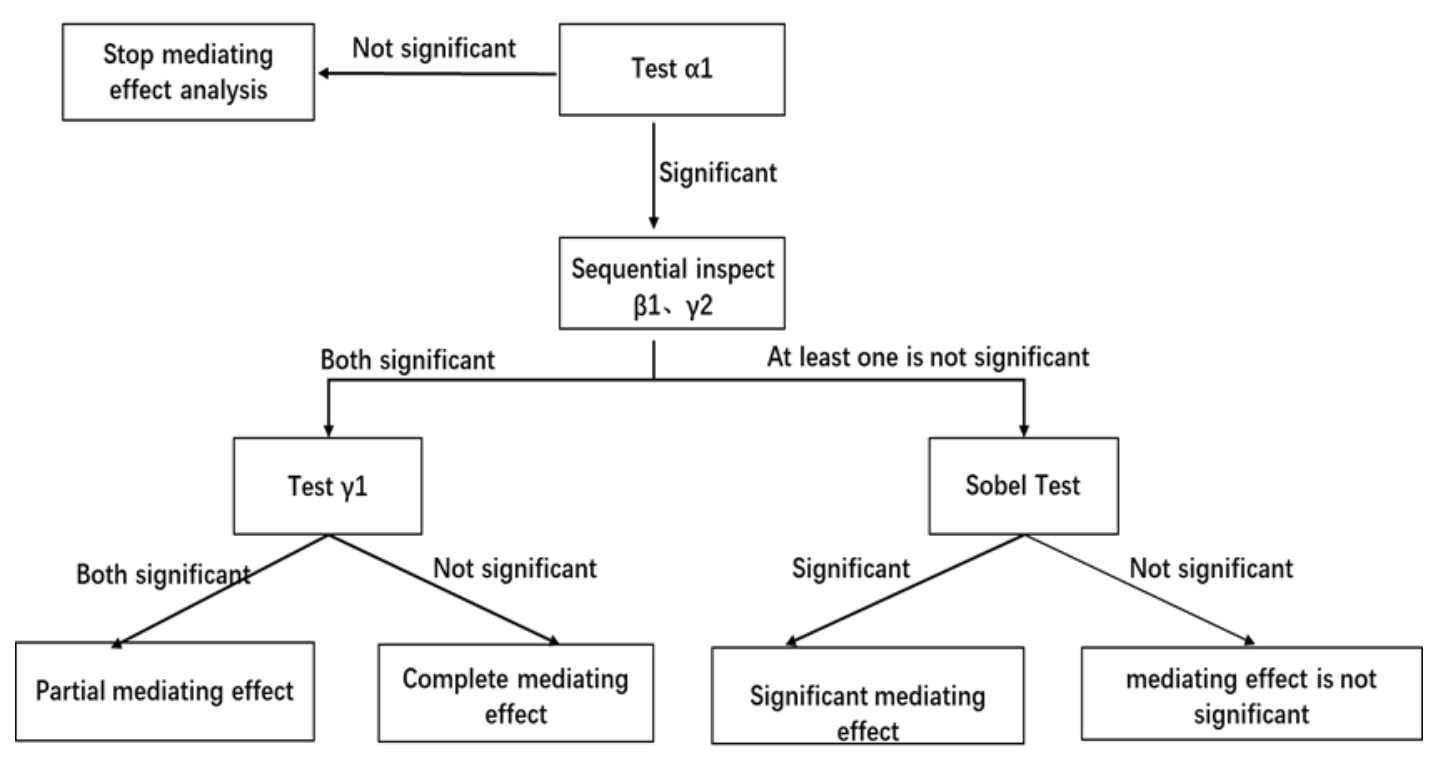

Fig. 2 The flow chart of mediating effect test

Next, the financial constraint index is divided into five elements to test the characteristics of enterprises that are suited to an improvement in financial performance through the implementation of CSR.

Model 3

$$
\begin{gathered}
R O A_{i t}=\gamma_{0}+\gamma_{1} E S G_{i t}+\gamma_{2} F C_{i t}+\gamma_{3} E S G * F C_{i t}+\gamma_{4} F C F_{i t}+\gamma_{5} D E B T_{i t}+\gamma_{6} A G E_{i t} \\
+\gamma_{7} S T A T E_{i t}+\gamma_{8} Y E A R_{i t}+\varepsilon_{i t}
\end{gathered}
$$

Model 4

$$
\begin{gathered}
R O E_{i t}=\gamma_{0}+\gamma_{1} E S G_{i t}+\gamma_{2} F C_{i t}+\gamma_{3} E S G * F C_{i t}+\gamma_{4} F C F_{i t}+\gamma_{5} D E B T_{i t}+\gamma_{6} A G E_{i t} \\
+\gamma_{7} S T A T E_{i t}+\gamma_{8} Y E A R_{i t}+\varepsilon_{i t}
\end{gathered}
$$

Model 5

$$
\begin{aligned}
& R O A_{i t}=\gamma_{0}+\gamma_{1} E S G_{i t}+\gamma_{2} \Delta P R_{i t}+\gamma_{3} S I Z E_{i t}+\gamma_{4} S L A C K_{i t}+\gamma_{5} C F / A_{i t}+\gamma_{6} S G R_{i t}+\gamma_{7} E S G \\
& * \Delta P R_{i t}+\gamma_{8} E S G * S I Z E_{i t}+\gamma_{9} E S G * S L A C K_{i t}+\gamma_{10} E S G * C F / A_{i t} \\
&+\gamma_{11} E S G * S G R_{i t}+\gamma_{12} F C F_{i t}+\gamma_{13} D E B T_{i t}+\gamma_{14} A G E_{i t}+\gamma_{15} S T A T E_{i t} \\
&+\gamma_{16} Y E A R_{i t}+\varepsilon_{i t}
\end{aligned}
$$

Model 6

$$
\begin{aligned}
& R O E_{i t}=\gamma_{0}+\gamma_{1} E S G_{i t}+\gamma_{2} \Delta P R_{i t}+\gamma_{3} S I Z E_{i t}+\gamma_{4} S L A C K_{i t}+\gamma_{5} C F / A_{i t}+\gamma_{6} S G R_{i t}+\gamma_{7} E S G \\
& * \Delta P R_{i t}+\gamma_{8} E S G * S I Z E_{i t}+\gamma_{9} E S G * S L A C K_{i t}+\gamma_{10} E S G * C F / A_{i t} \\
&+\gamma_{11} E S G * S G R_{i t}+\gamma_{12} F C F_{i t}+\gamma_{13} D E B T_{i t}+\gamma_{14} A G E_{i t}+\gamma_{15} S T A T E_{i t} \\
&+\gamma_{16} Y E A R_{i t}+\varepsilon_{i t}
\end{aligned}
$$


3.1 Variable definition:

3.1.1 Dependent variables: Referring to the research of De Lucia et al. (2020), this study adopts the ROA and ROE as alternative variables of financial performance.

\subsubsection{Independent variables:}

3.1.2.1 Financial constraint: Considering that the research samples of this study are listed companies in China, the financial constraint evaluation model developed by Zhai et al. (2012) is adopted as the alternative variable of financial constraint, and the evaluation model is as follows:

$$
\begin{gathered}
F C_{i, t}=-8.530658 * \Delta P R_{i, t}-0.4599886 * S I Z E_{i, t}-0.0030249 * S L A C K_{i, t} \\
-\frac{2.453183 * C F_{i . t}}{A_{i, t-1}}-1.304857 * S G R_{i, t}
\end{gathered}
$$

Among them, FC represents the degree of enterprise financial constraints, and the greater the absolute value of FC, the smaller the degree of financial constraints. $\triangle \mathrm{PR}$ represents the variation in cash dividends per share, that is, cash dividends per share in the current year minus cash dividends per share in the previous year. Size represents the scale of the company, expressed as the natural logarithm of the company's total assets at the end of the period. Slack is financial slack, and the calculation formula is [ (cash + trading financial assets $+0.5^{*}$ inventory $+0.7^{*}$ accounts receivable - short-term loans) / net value of fixed assets]. CF/A represents the proportion of cash flow in total assets at the end of the previous period. SGR is the growth rate of operating revenue $=[$ (operating revenue of the current year - operating revenue of last year) / operating revenue of last year]. Therefore, six variables are set based on the above formula: financial constraints (FC), cash dividend variation in the current year and last year $(\triangle \mathrm{PR})$, company size, slack, proportion of cash flow to total assets at the end of last year (CF/A) and growth rate of operating revenue (SGR). In this study's research model, the FC index and the five influencing factors take absolute values. The greater the absolute value, the smaller the degree of financial constraints.

3.1.2.2 Corporate social responsibility (ESG): This study uses the ESG rating results of the SinoSecurities index as an alternative variable of CSR. The rating results of the Sino-Securities index are divided into nine levels, from low to high: $\mathrm{C}, \mathrm{CC}, \mathrm{CCC}, \mathrm{B}, \mathrm{BB}, \mathrm{BBB}, \mathrm{A}, \mathrm{AA}$, and AAA. This study converted them into scores of 1-9 respectively.

3.1.2.3 Interaction terms of ESG and five elements of financial constraints: This study decentralized the variables of ESG, financial constraints, and detailed elements, and then set the interaction terms in the regression equation for analysis in order to explore the interaction of various factors causing financial constraints and corporate social responsibility. There are six variables: the interaction term of ESG and financial constraints (ESG*FC), ESG and cash dividend variation in the current year and last year(ESG* $\triangle \mathrm{PR}), \mathrm{ESG}$ and company scale (ESG *SIZE), ESG and financial slack (ESG*SLACK), ESG and the proportion of cash flow in total assets at the end of last year $(\mathrm{ESG} * \mathrm{CF} / \mathrm{A}), \mathrm{ESG}$ and operating revenue growth rate (ESG * SGR).

\subsubsection{Control variables:}

3.1.3.1 Scale: Choi and Wang (2009) argue that enterprise scale may affect enterprise performance because large enterprises have the advantage of economies of scale and can hedge against greater risks. In this study, the total assets of the sample companies were taken as an alternative variable of company size. To narrow the absolute value gap between this variable and other variables, and to avoid affecting the relative relationship, its natural logarithm is taken.

3.1.3.2 Free cash flow (FCF): This refers to the research findings of Yan and Wang (2021) which indicate that the level of free cash flow has a significant impact on investment efficiency. Considering that investment efficiency is closely related to financial performance, this study uses free cash flow as a control variable.

3.1.3.3 Operating revenue growth rate (RG): The research results of Maury and Pajuste (2005) show that the higher the growth rate of operating revenue, the more investors are optimistic about the future profitability of the company and will attract more investors. In this study, the variation 
in operating revenue is calculated, that is, the variation in operating revenue in the current year and the previous year. This is then divided by the revenue in the previous year.

3.1.3.4 Liability ratio (DEBT): Companies with high debt ratios are more likely to face default risk in the future, resulting in failure to repay debts. If the debt ratio is too high, it will affect the use of enterprise funds and consequently affect the profitability of enterprises. Referring to the practice of Margaritis and Psillaki (2007), this study measures the ratio of total liability to total assets.

3.1.3.5 Age of the company: Coad, Segarra, and Teruel (2013) pointed out that the company's age is related to the its performance and believed that the profitability and production efficiency of the company will change differently with different age stages. This study was conducted from the date of establishment to the end of the research year; therefore, this study uses company age as a control variable.

3.1.3.6 Property right nature (STATE): According to the research of Yan and Wang (2021), stateowned enterprises and non-state-owned enterprises have a significant impact on enterprise investment efficiency. The main variables of this study are financial constraints and financial performance, which are related to investment efficiency. Therefore, this study sets property right nature as one of the control variables, which is a virtual variable. If it is a state-owned enterprise, it is set as " 1 ," otherwise it is set as " 0. "

3.1.3.7 Industry (IND): Wang et al.'s(2020) study stated that, compared to traditional industries, the IT industry is characterized by obvious fluctuations and changes in financial performance. Therefore, this study adopts a dummy variable for the industries. The IT industry is set as " 1 " and the non-IT industry is set as " 0. "

3.1.3.8 Year (YEAR): Taking into account the impact of COVID-19 on the overall economy in 2020, this variable set the year as a control variable. This variable is a dummy variable. If the sample for 2019 is set to be " 0, " the sample in 2020 will be set as " 1. "

\section{Empirical results}

Table 1 shows the descriptive statistics of all variables, so we first conduct an overall review of all sample distributions.

Table 1 descriptive statistics $(\mathrm{N}=7,315)$

\begin{tabular}{lrrrr}
\hline & \multicolumn{1}{l}{ Min. } & \multicolumn{1}{l}{ Max. } & \multicolumn{1}{l}{ Ave. } & \multicolumn{1}{l}{ Std. } \\
\hline ROE & -1.1581 & 0.4047 & 0.0368 & 0.2058 \\
ROA & -0.7006 & 0.4393 & 0.0165 & 0.1369 \\
ESG & 3.0000 & 9.0000 & 6.2991 & 1.3075 \\
FC & 1.2027 & 13.2743 & 6.3337 & 1.6633 \\
$\Delta$ PR & -4.2653 & 4.7345 & 0.0275 & 1.0842 \\
SIZE & 4.8600 & 8.4140 & 6.0840 & 0.6745 \\
SLACK & -0.0046 & 0.8936 & 0.0343 & 0.1167 \\
CF/A & -0.5156 & 1.0794 & 0.0514 & 0.2254 \\
SGR & -0.9293 & 2.0363 & 0.0932 & 0.4169 \\
ESG*FC & -6.1311 & 7.7516 & 0.4413 & 1.8398 \\
ESG* $\Delta$ PR & -21.2629 & 21.8118 & 0.4592 & 8.4734 \\
ESG*SIZE & -17.4060 & 20.0384 & 0.0136 & 7.9923 \\
ESG*SLACK & -20.3960 & 19.2810 & 0.3691 & 8.0755 \\
ESG*CF/A & -0.3942 & 0.5072 & 0.0039 & 0.1013 \\
ESG*SGR & -0.9974 & 1.1015 & 0.0094 & 0.3239
\end{tabular}




\begin{tabular}{lrrrr} 
FCF & -0.8511 & 2.2716 & 0.0753 & 0.3359 \\
RG & -0.7122 & 1.5606 & 0.0714 & 0.3195 \\
DEBT & 0.0650 & 0.9763 & 0.4451 & 0.2137 \\
SCALE & 10.5730 & 18.2917 & 13.2264 & 1.4664 \\
AGE & 9.3178 & 35.1041 & 20.9103 & 5.5179 \\
STATE & 0.0000 & 1.0000 & 0.1329 & 0.3395 \\
IND & 0.0000 & 1.0000 & 0.1814 & 0.3854 \\
YEAR & 0.0000 & 1.0000 & 0.5150 & 0.4998 \\
\hline
\end{tabular}

Note 1: For the description of each variable, please refer to 3.1 "variable definition" in Section 3 "Methodology."

It can be seen from Table 1 that the samples obtained are complete in the high and low distribution of various variables, the samples of good and bad financial performance are all included, and the differences in the degree of financial constraints are significant. The performance of CSR includes A-to-C ratings, with obvious differentiation. The company scale and various financial indicators are also widely distributed, with a sample size of 7,315, which shows that this sample is sufficient and representative to a certain extent. It can be seen from the analysis of the mean value and standard deviation of each variable in the table that it is not normally distributed. Therefore, it is reasonable to winsorize the sample used in this study.

Next, Tables 2 to 6 present the empirical results of the regression and analysis. Before carrying out the empirical results, we first confirmed the various fitting indicators of the regression results. In the regression analysis from Table 2 to Table 6 , the adjusted R-square value is between 0.200 and 0.266 , which is a reasonable range in the discipline of social science, and the F value ranges from 191.085 to 267.767. These results indicate that the regression model design in this study is sufficiently predictive.

Table 2 The empirical results of model 1-2 and 2-2_The dependent variable is ESG $(\mathrm{N}=7,315)$

\begin{tabular}{lccr}
\hline & Coef. & $\mathrm{t}$ & $\mathrm{p}$ \\
\hline Constant term & 0.927 & 6.366 & $0.000^{* * *}$ \\
FC & -0.041 & -3.833 & $0.000^{* * *}$ \\
FCF & 0.100 & 2.285 & $0.022^{* *}$ \\
RG & 0.523 & 10.453 & $0.000^{* * *}$ \\
DEBT & -1.520 & -20.790 & $0.000^{* * *}$ \\
SCALE & 0.444 & 34.448 & $0.000^{* * *}$ \\
AGE & 0.015 & 5.997 & $0.000^{* * *}$ \\
STATE & 0.075 & 1.816 & $0.069 *$ \\
IND & -0.016 & -0.454 & 0.650 \\
YEAR & 0.130 & 4.736 & $0.000^{* * *}$ \\
\hline Aje R_sq. & & 0.214 & \\
\hline F Value & & $222.315^{* * *}$ & \\
\hline
\end{tabular}

Note 1: For the description of each variable, please refer to 3.1 "variable definition" in Section 3. "Methodology."

Note 2: $\mathrm{P}<=0.01$, the significance is $* * *, 0.01<\mathrm{p}<=0.05$, the significance is $* *, 0.05<\mathrm{p}<=$ 0.1 , the significance is $*$. 
As shown in Table 2, financial constraints (FC) have a negative and significant impact on the implementation of CSR, indicating that the greater the degree of financial constraints (the smaller the absolute value of FC), the worse the performance of enterprises in social responsibility.

Table 3 The empirical results of model 1_The dependent variable was ROA $(\mathrm{N}=7,315)$

\begin{tabular}{|c|c|c|c|c|c|c|}
\hline & \multicolumn{3}{|c|}{ Model 1-1 } & \multicolumn{3}{|c|}{ Model 1-3 } \\
\hline & Coef. & $\mathrm{t}$ & $\mathrm{P}$ & Coef. & $\mathrm{t}$ & $\mathrm{p}$ \\
\hline $\begin{array}{l}\text { Constant } \\
\text { term }\end{array}$ & -0.176 & -11.436 & $0.000 * * *$ & -0.185 & -12.043 & $0.000 * * *$ \\
\hline $\mathrm{FC}$ & 0.008 & 7.338 & $0.000 * * *$ & 0.018 & 7.717 & $0.000 * * *$ \\
\hline $\mathrm{FCF}$ & 0.019 & 4.175 & $0.000 * * *$ & 0.093 & 3.979 & $0.000 * * *$ \\
\hline RG & 0.098 & 18.570 & $0.000 * * *$ & -0.208 & 17.546 & $0.000 * * *$ \\
\hline DEBT & -0.223 & -28.826 & $0.000 * * *$ & 0.011 & -26.250 & $0.000 * * *$ \\
\hline SCALE & 0.016 & 11.424 & $0.000 * * *$ & 0.000 & 7.670 & $0.000 * * *$ \\
\hline AGE & 0.001 & 2.213 & $0.027 * *$ & 0.007 & 1.661 & $0.097^{*}$ \\
\hline STATE & 0.007 & 1.703 & $0.089 *$ & -0.014 & 1.541 & 0.123 \\
\hline IND & -0.014 & -3.720 & $0.000 * * *$ & 0.025 & -3.693 & $0.000 * * *$ \\
\hline YEAR & 0.026 & 9.102 & $0.000 * * *$ & 0.010 & 8.687 & $0.000 * * *$ \\
\hline ESG & - & - & - & 0.009 & 7.946 & $0.000 * * *$ \\
\hline AjeR_sq. & & \multicolumn{2}{|c|}{0.200} & \multicolumn{3}{|c|}{0.206} \\
\hline F Value & & \multicolumn{2}{|c|}{$203.570 * * *$} & \multicolumn{3}{|c|}{$191.085 * * *$} \\
\hline
\end{tabular}

Note 1: For the description of each variable, please refer to 3.1 "variable definition" in Section 3.

"Methodology."

Note 2: $\mathrm{P}<=0.01$, the significance is $* * *, 0.01<\mathrm{p}<=0.05$, the significance is $* *, 0.05<\mathrm{p}<$ $=0.1$, the significance is $*$.

Table 4 The empirical results of models $2-1$ and 2-3_The dependent variable is $\operatorname{ROE}(\mathrm{N}=7,315)$

\begin{tabular}{|c|c|c|c|c|c|c|}
\hline \multicolumn{4}{|c|}{ Model 2-1 } & \multicolumn{3}{|c|}{ Model 2-3 } \\
\hline & Coef. & $\mathrm{t}$ & $\mathrm{P}$ & Coef. & $\mathrm{t}$ & $\mathrm{p}$ \\
\hline $\begin{array}{l}\text { Constant } \\
\text { term }\end{array}$ & -0.319 & -14.203 & $0.000 * * *$ & -0.341 & -15.372 & $0.000 * * *$ \\
\hline $\mathrm{FC}$ & 0.006 & 3.493 & $0.000 * * *$ & 0.007 & 4.153 & $0.000 * * *$ \\
\hline $\mathrm{FCF}$ & 0.021 & 3.078 & $0.002 * * *$ & 0.018 & 2.748 & $0.006^{* * *}$ \\
\hline $\mathrm{RG}$ & 0.186 & 24.149 & $0.000 * * *$ & 0.173 & 22.604 & $0.000 * * *$ \\
\hline DEBT & -0.385 & -34.154 & $0.000 * * *$ & -0.347 & -30.351 & $0.000 * * *$ \\
\hline SCALE & 0.036 & 17.938 & $0.000 * * *$ & 0.025 & 11.690 & $0.000 * * *$ \\
\hline $\mathrm{AGE}$ & 0.000 & 0.551 & 0.582 & 0.000 & -0.409 & 0.682 \\
\hline STATE & 0.009 & 1.426 & 0.154 & 0.007 & 1.151 & 0.250 \\
\hline IND & -0.034 & -6.092 & $0.000 * * *$ & -0.033 & -6.097 & $0.000 * * *$ \\
\hline YEAR & 0.008 & 1.949 & $0.051 *$ & 0.005 & 1.207 & 0.227 \\
\hline ESG & - & - & - & 0.025 & 13.806 & $0.000 * * *$ \\
\hline AjeR_sq. & & \multicolumn{2}{|c|}{0.247} & \multicolumn{3}{|c|}{0.266} \\
\hline F Value & & \multicolumn{2}{|c|}{$267.767 * * *$} & \multicolumn{3}{|c|}{$266.307 * * *$} \\
\hline
\end{tabular}


Note 1: For the description of each variable, please refer to 3.1 "variable definition" in Section 3. "Methodology."

Note 2: $\mathrm{P}<=0.01$, the significance is $* * *, 0.01<\mathrm{p}<=0.05$, the significance is $* *, 0.05<\mathrm{p}<=$ 0.1 , the significance is $*$.

Models 1-1 and 1-3 in Table 3 and 1-2 in Table 2 are affiliated to model 1, while models 2-1 and 2-3 in Table 4 and 1-2 in Table 2 belong to model 2 . The empirical results for the two models are approximately the same. A comparison of models 1-1 and 1-3 and models 2-1 and 2-3 reveals that when the FC value is greater (the degree of financial constraint is smaller), it has a significant impact on financial performance (return on total assets and return on equity) in the same direction. However, after adding the variable influence of ESG, except that ESG has a significant positive impact on financial performance, the impact of financial constraints on financial performance is more significant ( $\mathrm{t}$ value increases), indicating that the impact on the improvement of financial performance is more obvious. The empirical results in Tables 3, 4, and 2 show that ESG has partial mediation effects between financial constraints and financial performance according to the intermediary effect judgment process in Figure 1.

Next, we add the interaction of CSR and financial constraints to investigate the impact of enterprises with large financial constraints on financial performance through the implementation of CSR. The empirical results are presented in Tables 5 and 6 . Table 5 presents the overall indicators of financial constraints as variables, and Table 6 sets different variables for the five elements of financial constraints to test their respective effects.

Table 5 The empirical results of model 3 and model $4(\mathrm{~N}=7,315)$

\begin{tabular}{lrrr|rrr}
\hline & \multicolumn{3}{c|}{ ROA } & \multicolumn{3}{c}{ ROE } \\
\hline & Coef. & \multicolumn{1}{c}{$\mathrm{t}$} & $\mathrm{p}$ & \multicolumn{1}{c}{ Coef. } & $\mathrm{t}$ \\
\hline Constant & -0.191 & -12.460 & $0.000^{* * *}$ & -0.349 & -15.709 & $0.000^{* * *}$ \\
term & & & & & \\
ESG & 0.009 & 7.124 & $0.000^{* * *}$ & 0.023 & 13.083 & $0.000^{* * *}$ \\
FC & 0.010 & 8.610 & $0.000^{* * *}$ & 0.008 & 4.906 & $0.000^{* * *}$ \\
ESG*FC & -0.005 & -6.693 & $0.000^{* * *}$ & -0.006 & -5.554 & $0.000^{* * *}$ \\
FCF & 0.020 & 4.246 & $0.000^{* * *}$ & 0.020 & 2.965 & $0.003^{* * *}$ \\
RG & 0.088 & 16.378 & $0.000^{* * *}$ & 0.167 & 21.544 & $0.000^{* * *}$ \\
DEBT & -0.202 & -25.508 & $0.000^{* * *}$ & -0.341 & -29.687 & $0.000^{* * *}$ \\
SCALE & 0.012 & 8.025 & $0.000^{* * *}$ & 0.025 & 11.982 & $0.000^{* * *}$ \\
AGE & 0.000 & 1.522 & 0.128 & 0.000 & -0.529 & 0.597 \\
STATE & 0.006 & 1.343 & 0.179 & 0.006 & 0.985 & 0.324 \\
IND & -0.014 & -3.637 & $0.000^{* * *}$ & -0.033 & -6.053 & $0.000^{* * *}$ \\
YEAR & 0.025 & 8.714 & $0.000^{* * *}$ & 0.005 & 1.210 & 0.226 \\
\hline AjeR_sq. & \multicolumn{7}{c|}{0.211} & & 0.269 & \\
\hline F Value & \multicolumn{7}{c|}{$178.827^{* * *}$} & & $245.890^{* * *}$ & \\
\hline
\end{tabular}

Note 1: For the description of each variable, please refer to 3.1 "variable definition" in Section 3.

"Methodology."

Note 2: $\mathrm{P}<=0.01$, the significance is $* * *, 0.01<\mathrm{p}<=0.05$, the significance is $* *, 0.05<\mathrm{p}<=$ 0.1 , the significance is $*$.

Table 6 The empirical results of model 5 and Model $6(\mathrm{~N}=7,315)$ 


\begin{tabular}{|c|c|c|c|c|c|c|}
\hline & \multicolumn{3}{|c|}{$\mathrm{ROA}$} & \multicolumn{3}{|c|}{ ROE } \\
\hline & Coef. & $\mathrm{t}$ & $\mathrm{p}$ & Coef. & $\mathrm{t}$ & $\mathrm{p}$ \\
\hline Constant term & -0.639 & -7.134 & $0.000 * * *$ & -0.693 & -5.360 & $0.000 * * *$ \\
\hline ESG & 0.079 & 5.745 & $0.000 * * *$ & 0.078 & 3.929 & $0.000 * * *$ \\
\hline$\Delta \mathrm{PR}$ & 0.011 & 7.882 & $0.000 * * *$ & 0.007 & 3.631 & $0.000 * * *$ \\
\hline SIZE & 0.036 & 12.166 & $0.000 * * *$ & 0.062 & 14.665 & $0.000 * * *$ \\
\hline SLACK & -0.021 & -1.702 & $0.089 *$ & -0.035 & -1.997 & $0.046 * *$ \\
\hline $\mathrm{CF} / \mathrm{A}$ & 0.054 & 8.199 & $0.000 * * *$ & 0.088 & 9.178 & $0.000 * * *$ \\
\hline SGR & 0.076 & 21.348 & $0.000 * * *$ & 0.133 & 25.846 & $0.000 * * *$ \\
\hline $\mathrm{ESG}^{*} \Delta \mathrm{PR}$ & -0.002 & -1.605 & 0.109 & 0.002 & 1.061 & 0.289 \\
\hline ESG*SIZE & 0.000 & -0.165 & 0.869 & -0.002 & -1.164 & 0.244 \\
\hline ESG*SLACK & -0.010 & -4.747 & $0.000 * * *$ & -0.014 & -4.568 & $0.000 * * *$ \\
\hline $\mathrm{ESG}^{*} \mathrm{CF} / \mathrm{A}$ & 0.010 & 0.612 & 0.541 & 0.048 & 1.991 & $0.047 * *$ \\
\hline ESG*SGR & -0.012 & -1.978 & $0.048 * *$ & -0.059 & -6.634 & $0.000 * * *$ \\
\hline $\mathrm{FCF}$ & 0.026 & 5.428 & $0.000 * * *$ & 0.027 & 4.054 & $0.000 * * *$ \\
\hline DEBT & -0.196 & -24.725 & $0.000 * * *$ & -0.332 & -29.057 & $0.000 * * *$ \\
\hline $\mathrm{AGE}$ & 0.001 & 2.257 & $0.024 * *$ & 0.000 & 0.176 & 0.860 \\
\hline STATE & 0.003 & 0.814 & 0.416 & 0.002 & 0.373 & 0.709 \\
\hline IND & -0.013 & -3.511 & $0.000 * * *$ & -0.032 & -5.910 & $0.000 * * *$ \\
\hline YEAR & 0.023 & 7.956 & $0.000 * * *$ & 0.001 & 0.205 & 0.837 \\
\hline AjeR_sq. & \multicolumn{3}{|c|}{0.221} & \multicolumn{3}{|c|}{0.283} \\
\hline F Value & \multicolumn{3}{|c|}{$123.380 * * *$} & \multicolumn{3}{|c|}{$170.516^{* * *}$} \\
\hline
\end{tabular}

Note 1: For the description of each variable, please refer to 3.1 "variable definition" in Section 3.

"Methodology."

Note 2: $\mathrm{P}<=0.01$, the significance is $* * *, 0.01<\mathrm{p}<=0.05$, the significance is $* *, 0.05<\mathrm{p}<$ $=0.1$, the significance is $*$.

The empirical results in Table 5 indicate that the better the performance of social responsibility, the lower the degree that financial constraints will help to improve financial performance. However, Table 6 presents the interaction of ESG for the five elements affecting financial constraints for a detailed analysis of the characteristics of enterprises that are more suitable for improving financial performance by implementing CSR. The results show that in the context of return on total assets, when the factors of dividend payout rate, assets scale, and the proportion of cash flow in the total assets at the end of last year lead to greater financial constraints and declining financial performance, CSR implementation is ineffective in improving financial performance. However, if a high degree of financial constraints are caused by the factors of financial slack and the growth rate of operating revenue, it will be helpful to enhance financial performance by implementing CSR programs.

As for the ROE, for enterprises with poor financial performance due to high financial constraints caused by dividend payout rate and assets scale, the implementation of CSR has no significant impact on the improvement of financial performance. However, if a high degree of financial constraint is caused by financial slack and the growth rate of operating revenue, the implementation of CSR is an effective strategy to improve financial performance. Nevertheless, for enterprises with a high proportion of cash flow in total assets at the end of last year, the results in Table 5 indicate 
that although the interaction terms with ESG show a positive significant impact, they are significantly lower than those without ESG ( $t$ value decreases).

It should be noted that most of the above results indicate a negatively significant relationship with financial performance in the interaction terms, implying that the greater the degree of financial constraints, the greater the mediating effect of CSR. However, if the financial constraints are smaller, that is, the greater the interaction terms of ESG and financial constraints, it will have an adverse impact on financial performance. According to Bernanke \& Gertler's (1989) financial constraint theory, enterprises' investment will be affected by their own internal capital. It may be that enterprises with fewer financial constraints can leverage more investment tools to obtain greater financial profits.

\section{Conclusions}

\subsection{Theoretical meaning:}

The results of this study indicate that the degree of financial constraints has a negatively significant impact on enterprise financial performance, that is, the greater the degree of financial constraint, the lower the financial performance. CSR plays a mediating role between financial constraints and financial performance. The empirical results of this study are summarized as follows:

- The degree of corporate financial constraints has a significant negative impact on financial performance.

- There is a negative relationship between the degree of corporate financial constraints and performing CSR.

- Enterprises with high financial constraints due to the factors of financial slack and growth rate of operating revenue can significantly improve their financial performance through the implementation of CSR.

- If enterprises with smaller financial constraints invest too much in CSR, it will have a negative impact on financial performance.

\subsection{Practical meaning}

Based on the empirical results and research findings of this study, the following suggestions are proposed:

1. For enterprises: When the degree of financial constraints is high, many enterprises will choose to minimize expenditures. As there are currently no mandatory laws and policies for corporate social responsibility, relevant expenditures are easier to cut. However, many factors cause financial constraints. Financial slack and operating revenue growth are closely related to sales strategy, consumer recognition, and bank interaction. The implementation of CSR is the most effective way to improve the relationship with banks, consumers, and other stakeholders. Therefore, in the case of enterprises with high financial constraints due to financial slack and the growth rate of operating revenue, CSR strategies should be formulated more effectively to improve financial performance. However, enterprises with small financial constraints have many more investment targets and are more likely to achieve greater investment efficiency. Therefore, CSR spending does not need to be increased; otherwise, it will weaken financial performance.

2. For regulators and policymakers: Based on the different operating conditions of each enterprise, there is no specific standard for the implementation of CSR, but enterprises are encouraged to 
implement it. However, according to the empirical results of this study, the CSR implementation does contribute to the "win-win" effect between enterprises and stakeholders. Therefore, this study suggests that the state should formulate flexible policies, strengthen publicity, and strengthen the motivation and action of enterprises to undertake social responsibility, so as to improve economic development and social welfare.

5.3 Research limitation

At present, CSR evaluation indicators include social contribution per share and ESG ratings with several institutions. However, each rating standard is different. Considering the integrity of the sample, this study only selects the rating results of Sino-Securities Index with a wide rating range.

\section{Reference}

1. Bernanke, B. and Gertler, M. (1989). Agency Cost, Net Worth, and Business Fluctuations. The American Economics Review, 79(1), 14-31.

2. Broadstock, D. C., Matousek, R., Meye, M. and Tzeremes, N. G. (2020). Does corporate social responsibility impact firms' innovation capacity? The indirect link between environmental \& social governance implementation and innovation performance. Journal of Business Research, 119, 99-110.

3. Brogi M. and Lagasio, V. (2018). Environmental, social, and governance and company profitability: Are financial intermediaries different? Corporate Social Responsibility and Environmental Management, 26(3), 576-587.

4. Chen, J. and Zheng, H. (2020). Financing Constraints, Customer Bargaining Ability and Corporate Social Responsibility. Accounting Research, 8, 50-63.

5. Choi, J. and Wang, H. (2009). Stakeholder relations and the persistence of corporate financial performance. Strategic management journal, 30(8), 895-907.

6. Coad, A., Segarra, A. and Teruel, M. (2013). Like milk or wine: Does firm performance improve with age? Structural Change and Economic Dynamics, 24, 173-189.

7. De Lucia C., Pazienza P. and Bartlett, M. (2020). Does Good ESG Lead to Better Financial Performances by Firms? Machine Learning and Logistic Regression Models of Public Enterprises in Europe. Sustainability, 12, 5317.

8. Fazzari, S., Hubbard, R. and Petersen, B. (1988). Investment, Financial Decisions, and Tax Policy. American Economic Review, 78(2), 200-205.

9. Greewald, B., Stiglitz, JE and Weiss, A. (1984). Informational Imperfections in the Capital-market and Macroeconomic Fluctuations. American Economic Review, 74(2), 194199.

10. Gu, L., Li, J. and Peng, Y. (2018). Financing Conditions, Financing Constraints and Firm Performance. Economic Theory and Business Management, 7, 88-99.

11. Hadlock, CJ and Pierce, JR. (2010). New Evidence on Measuring Financial Constraints: Moving Beyond the KZ Index. Review of Financial Studies, 23(5), 1909-1940.

12. Jiang, F., Cai, W., Cai, X, and Li, X. (2019). Microeconomic Effects of Bank Competition: Evidence from Corporate Financial Constraints. Economic Research Journal, 54 (06), 72-88. 
13. Kaplan, S. N. and Zingales, L. (1997). Do Investment-Cash Flow Sensitivities Provide Useful Measures of Financial Constraints? Quarterly Journal of Economics, 112(1), 169215.

14. Kim, S., and Li, Z. C. (2021). Understanding the Impact of ESG Practices in Corporate Finance. Sustainability, 2021, 13(7), 3746.

15. Lamont, O., Polk, C. and Saa-Requejo, J. (2001). Financial Constraints and Stock Returns. Review of Financial Studies, 14(2), 529-554.

16. Leong, C. K. and Yang, Y. C. (2021). Constraints on "Doing Good": Financial constraints and corporate social responsibility. Finance Research Letters, 40, 101694.

17. Li, X., Fung, HG, Zhu, Q. and Liu, Z. (2020). Interlocking Directorate Networks, Financial Constraints and the Social Responsibility of Private Enterprises. Chinese Journal of Management, 17(8), 1208-1217.

18. Li, Y., Pang, H. and Pang, H. (2021). Research on the relationship between financing constraints and enterprise performance -- from the perspective of economic policy uncertainty and internal control. Friends of Accounting, 2, 49-55.

19. Liu, L. and Xu, W. (2021). Comparative study on enterprise ESG evaluation and traditional credit rating system. New Finance, 4, 59-64.

20. Margaritis, D. and Psillaki, M. (2007). Capital structure and firm efficiency. Journal of Business Finance \& Accounting, 34(9-10), 1447-1469.

21. Maury, B. and Pajuste, A. (2005). Multiple large shareholders and firm value. Journal of Banking and Finance, 29(7), 1813-1834.

22. Modigliani, F. and Miller, M. H. (1958). The Cost of Capital, Corporation Finance and the Theory of Investment. The American Economic Review, 48(3), 261-297.

23. Myers, SC and Majluf, NS (1984). Corporate Financial and Investment Decisions When Firms Have Information that Investors Do Not Have. Journal of Financial Economics, 13(2), 187-221.

24. Uyar, A., Kilic, M., Koseoglu, MA, Kuzey, C. and Karaman, A. S. (2020). The link among board characteristics, corporate social responsibility performance, and financial performance: evidence from the hospitality and tourism industry. Tourism Management Perspectives, 35, 100714.

25. Wang, H,-M., Yu, T, H.-K. and Hsiao, C.-Y. (2020). The Causal Effect of Corporate Social Responsibility and Corporate Reputation on Brand Equity: A Fuzzy-Set Qualitative Comparative Analysis. Journal of Promotion Management, 27(5), 630-641.

26. Wen, Z. and Ye B. (2014). Analyses of Mediating Effects: The Development of Methods and Models. Advances in Psychological Science, 22 (5), 731-745.

27. Whited, T. M. and Wu, G. (2006). Financial constraints risk. Review of Financial Studies, 2, 531-559.

28. Yan, R., Jiang, X. (2019).The Multiple Relationship Model and Empirical Research of Institutional Environment, Political Connections, Financing Constraints and R\&D Investment. Chinese Journal of Management, 2019, 16(01), 72-84. 
29. Yan, S. and Wang, D. (2021).“The Belt and Road”Corporate Social Responsibility, Financing Constraints and Investment Efficiency. Finance \& Economics, 2, 45-55.

30. Zhai, S., Geng, J. and Han, Y. (2012). Design and Efficiency Evaluation of Financial Constraint Index: Based on The Empirical Analysis Using the Panel Data of A-Share Companies. Modern Finance and Economics-Journal of Tianjin University of Finance and Economics, 32 (7), 46-58.

31. Zhang, H., Zhou, Y., Yin, H., Ma, S., Yang, X., Qiu, M. and Zhang, J. (2017). Research on ESG green rating and green index. Financial Forum, 2017, 22 (9), 3-14.

32. Zhang, L., Mo, Y., Xia, X. and Pu, L. (2020). Research on the Relationship among Financial Constraints, Investment Efficiency and Corporate Performance of Chinese Listed Companies Based on Financial Balance: Panel Data of Shanghai and Shenzhen A-share Listed Companies from 2012 to 2018. Journal of Technology Economics, 39 (12), 51-60.

33. Zhang, X., Li, Z. and Li, C. (2019). Banking Competition, FInancial Constraints, and Corporate Innovation: Evidence from Industrial Firms in China. Journal of Financial Research, 10, 98-116.

34. Zhang, Y., Qiang, C., Gao, L. and Zhou, X. (2021). Financial constraints, commercial credit and financial performance of private enterprises. Friends of Accounting, 10, 67-73.

35. Zhong, P., Wu, T. and Li, X. (2021). An Empirical Study on the Relationship among Corporate Social Responsibility Report, Social Irresponsibility and Financial Performance of Listed Companies. Forecasting, 40(1), 17-23.

36. Zhu, Y., Xue, W. and An, Z. (2016). Financial constraints, corporate social responsibility performance and corporate performance. Finance and Accounting Monthly, 2016 (10), 27-31. 